\title{
THE FIRST AMENDMENT AND CYBERSPACE: THE CLINTON YEARS
}

\author{
JAMES BOYLE*
}

I

\section{INTRODUCTION}

There are many things one could say about the Clinton Administration's effect on the Constitution. I am tempted to comment generally about the Clinton Administration's concern for constitutional values, but Dean Nichol has already captured many of my feelings on that subject. ${ }^{1}$ In any event, my assigned topic was a narrower one: the Clinton Administration's impact on speech in cyberspace. I take as my starting point the bracing skepticism of Professor Volokh's paper on the same subject, a subject about which he has considerable doubt:

I was asked to participate in this symposium by discussing the Clinton Administration and free speech in cyberspace, and I will do so. But inquiring into the Clinton Administration's role in cyberspace speech regulation may be asking the wrong question. I'm not sure that particular Administrations generally have much of a direct impact on free speech law (as opposed to the indirect impact, often not seen for decades, flowing from the decisions of the judges they appoint). The Clinton Administration, for instance, has mostly confronted free speech law incidentally and sporadically; the high-profile direct attempts to seriously restrict speech, such as the [Communications Decency Act], have largely come from Congress.

Moreover, the words "in cyberspace" in the phrase "restrictions on free speech in cyberspace" are generally, in my view, not terribly significant; the medium by and large does not and should not affect the protection-or lack of protection-given to the content. ${ }^{2}$

I am going to disagree, at least in emphasis, with most of these claims. In fact, there are interesting questions to be asked about the Clinton

Copyright (C 2000 by James Boyle

This article is also available at http://www.law.duke.edu/journals/63LCPBoyle.

* Professor of Law, Duke University.

1. See Gene R. Nichol, Taking Economic Equality Off the Table, 63 LAW \& CONTEMP. ProBS. 353 (Winter/Spring 2000). A more jurisprudential approach might also be interesting. A deconstructionist could make much of the implicit structure of the political attacks on President Clinton's personality and his style of governance; both are asserted to have "constitutional" deficiencies and the predominant critique is one central to conventional constitutional scholarship-the triumph of expedient "policy" over higher "principle"-indicating the extent to which such divisions are central even to our non-legal discourse about morality and politics. See generally James Boyle, Anachronism of the Moral Sentiments? Integrity, Post-modernism and Justice, 51 STAN. L. REV. 493 (1999).

2. Eugene Volokh, Freedom of Speech, Cyberspace, Harassment Law, and the Clinton Administration, 63 LAW \& CONTEMP. PROBS. 299, 302 (Winter/Spring 2000). Given his skepticism about the topic, our papers diverge here, his going on to write about sexual harassment and mine focusing on the tension between the First Amendment and current intellectual property policy. 
Administration's role in cyberspace speech regulation. Indeed, the actions of this Administration have had and will continue to have a considerable impact on both speech regulation in cyberspace, and on the law of the First Amendment generally. Finally, although Professor Volokh makes the valid point that discussions of free speech should not be medium-specific, certain particular features of cyberspace in general, and of the Clinton Administration's "plan" for cyberspace in particular, are likely to force the courts to confront a series of tensions and omissions in First Amendment doctrine. Admittedly, the Clinton Administration's role of "making" free speech law in some of these cases is similar to the Nixon Administration's role in "making" law on executive privilege, ${ }^{3}$ another area in which the current Administration has excelled. ${ }^{4}$ However, both in terms of speech regulation and in terms of providing raw material for the legal controversies that shape the law of the First Amendment, the Clinton Administration's legacy is considerable, and nowhere more than in cyberspace. ${ }^{5}$

\section{II}

\section{A WORLD WITHOUT SULLIVAN}

The most visible examples of the Clinton Administration's role in cyberspeech regulation are the Communications Decency Act ("CDA"), which was struck down by unanimous vote of the Supreme Court in $1997,{ }^{7}$ and the Child Online Protection Act ("COPA"), which is now before the courts." Both of these pieces of legislation were supported by the Clinton Administration even though the CDA had so many First Amendment problems it read like a law school exam question, and the COPA, while much better drafted, is hardly solicitous of speech on the Internet. ${ }^{10}$ In my view, Professor Volokh is a little quick to let the Clinton Administration off the hook for its role in these bills; others have certainly been more critical. ${ }^{11}$ Although the main impetus for the

3. See, e.g., United States v. Nixon, 418 U.S. 683 (1974).

4. See, e.g., Clinton v. Jones, 520 U.S. 681 (1997).

5. I am not entirely sure whether Professor Volokh would disagree with my analysis. He has certainly written persuasively about the First Amendment analysis of intellectual property. Eugene Volokh \& Brett McDonnell, Freedom of Speech and Independent Judgment Review in Copyright Cases, 107 YALE L.J. 2431 (1998).

6. See Telecommunications Act of 1996, 47 U.S.C. § 223(a)(1)(B) (1996); id. § 233(d)(1) (1998).

7. See ACLU v. Reno I, 521 U.S. 844 (1997).

8. Child Online Protection Act, 14 U.S.C. $\S 1401-1406,47$ U.S.C. $§ 231$ (1998).

9. See, e.g., ACLU v. Reno II, 31 F. Supp. 2d 473 (1999).

10. My students and I have analyzed the constitutional problems of both of these pieces of legislation at some length. For the CDA, see Before the Supreme Un-Court of the United States (visited Mar. 22, 2000) <http://www.wcl.american.edu/pub/faculty/boyle/unreno.htm>. For the COPA, see Before the Supreme Un-Court of the United States (visited Mar. 22, 2000) $<$ http://www.law.yale.edu/censor/uncopa.htm >.

11. An article by Floyd Abrams, the noted First Amendment lawyer, provides a fairly typical assessment:

At 10 a.m. on March 19, the nine justices of the United States Supreme Court walked to their leather chairs, which faced the attorneys before them. On one side of a podium were lawyers 
legislation came from the Congress, not from the Administration, the President publicly supported and signed both bills without any apparent qualms, which is itself quite striking. Even if one believes strongly in the desirability and constitutionality of the regulation of minors' online access to indecent material, both prudence and institutional responsibility argue for some level of constitutional scrutiny before the President signs a particular bill; under normalscience constitutional analysis, the CDA was so palpably unconstitutional that the Clinton Administration garners little credit on either front. As soon as the Court ruled, however, President Clinton characteristically "praised the court's decision to protect free speech and expression on the Internet," First Amendment issue had not been mentioned to him before. The Administration subsequently distanced itself from the bill in favor of a declared "hands-off" regulatory style under the unlikely, but competent, leadership of Ira Magaziner. ${ }^{13}$

Nevertheless, Professor Volokh is correct to say that the Clinton Administration was not the effective moving force for either piece of legislation. Thus, it is reasonable to conclude that in terms of traditional, direct attempts to regulate speech on the Internet, the Clinton Administration has not had a large impact.

It is at this point, however, that I must part company with Professor Volokh. On a broader and perhaps more significant level, the Clinton Administration has played a large role in the law and policy of online speech regulation both by sponsoring and administering regulatory initiatives, and by creating the controversies that will shape First Amendment jurisprudence over the next fifteen to twenty years.

To set up my argument, I must ask you to engage in a thought experiment. Imagine the law of the First Amendment without New York Times v. Sullivan ${ }^{14}$

for a coalition of civil liberties and computer-industry groups prepared to argue that the Communications Decency Act signed into law by President Clinton last year violated the First Amendment. Standing on the other side, ready to defend the constitutionality of the law, were lawyers for Attorney General Janet Reno and, by extension, President Clinton himself. From any First Amendment perspective, it was a depressingly familiar sight. Government lawyers routinely defend governmental conduct. But it has become the norm, not the exception, for Clinton Administration lawyers to find themselves minimizing First Amendment interests and defending laws or policies that maximize threats to free expression. Time and again, the Administration has opposed serious First Amendment claims in court, acquiesced in serious First Amendment damage by legislation and ignored First Amendment limits in its own conduct. Even when the Administration has raised First Amendment concerns, it has done so haltingly and briefly.

Floyd Abrams, Clinton vs. the First Amendment, N.Y. Times, Mar. 30, 1997, § 6, at 42.

12. Supreme Court Strikes Down Communications Decency Act; Law Unduly Curbs Free Speech, FACTS ON FILE WORLD NEWS DIGEST, July 3, 1997, at A1, 473, available in LEXIS, News Library, Facts File.

13. Matt Pottinger, White House Rejects Communications Decency Act; Outlines Strategy for Internet Commerce, STATES NEWS SERVICE, Apr. 1, 1997, available in LEXIS, News Library, SNS File. As I will show later, the hands-off approach did not extend to intellectual property. See infra text accompanying notes $17-24$.

14. New York Times Co. v. Sullivan, 376 U.S. 254 (1964). 
and its progeny. ${ }^{15}$ Imagine that the Court had rejected-or never clearly faced-the claim that the First Amendment could somehow require a constitutional modification to the substantive law of defamation in every state, a "federal rule that prohibits a public official from recovering damages for a defamatory falsehood relating to his official conduct unless he proves that the statement was made with 'actual malice'-that is, with knowledge that it was false or with reckless disregard of whether it was false or not." ${ }^{16}$ After all, Sullivan was a civil lawsuit between private parties, enforcing a facially neutral law that gave no special privileges to incumbents or state officials. True, given the difficulty of verifying every statement, a particular background regime of libel law might, in practice, allow incumbents or state officials to stifle the speech of critics or journalists. Where the threat of litigation did not suffice, libel law might even allow officials to use state power to silence their opponents. But if this is enough to qualify as state action, enough to require a specific constitutionally mandated modification to the substantive private law of every state, has not the court returned to the supposed excesses of Shelley $v$. Kraemer? ${ }^{17}$

In this Sullivan-less world, then, imagine an administration that moved decisively to "strengthen" the law of defamation, federalizing large chunks of it, dramatically expanding the definition of defamation, the remedies available to those defamed, and the list of parties who might be held contributorily or vicariously liable. The definition of reputational injury could be broadened, proof requirements eased, the right against defamation made to survive the death of the person defamed, the plaintiff given injunctive rights to stop publication and even the right to seize any computer that might have been used to defame or was likely to be used to defame someone in the future. Imagine also that this administration, faced with the dramatic expansion of the Internet, made protection against defamation its key policy initiative both domestically and internationally, encouraging other nations to adopt similarly expansive definitions of defamation and threatening those that did not with trade sanctions. Online service providers could be made strictly liable for defamation committed by their users; anonymity (long a tool of the slanderer) could be discouraged by technical standards backed by the power of the federal government's purchasing power and perhaps even imposed by force of law. The administration would argue that without security against reputational injury, commerce and speech on the Internet are unlikely to flourish-who would venture online without a legal guarantee that they are secure from the

15. See, e.g., Hustler v. Falwell, 485 U.S. 46 (1988) (applying the logic of Sullivan to intentional infliction of emotional distress); Philadelphia Newspapers, Inc. v. Hepps, 475 U.S. 767 (1986) (requiring a private plaintiff to show falsity of an allegedly libelous statement to recover damages); Curtis Publishing Co. v. Butts, 388 U.S. 130 (1967) (expanding public figure concept); see also Wolston v. Reader's Digest Ass'n Inc., 443 U.S. 157 (1979); Gertz v. Robert Welch, Inc., 418 U.S. 323 (1974).

16. Sullivan, 376 U.S. at 279-80.

17. 334 U.S. 1 (1948). The importance of Sullivan's treatment of state action was pointed out 35 years ago by my colleague William Van Alstyne. See William W. Van Alstyne, Mr. Justice Black, Constitutional Review and the Talisman of State Action, 1965 DUKE L.J. 219. 
words of the malicious, or simply the careless? The administration might even propose federal legislation and international treaties that would define new types of reputational interests, promising a constellation of entirely new legal protections surrounding the traditional law of libel and slander.

My point is that, even if we lacked the rules laid down in Sullivan, we would see clearly that our hypothetical administration was implicated in a set of dramatic regulations of speech, and cyber-speech in particular. The effects of these regulations would not be simple, of course. Using the law to guarantee freedom from reputational injury might actually encourage some people to join the debate who otherwise would remain on the sidelines. It might also sometimes force journalists to be more careful, thereby improving the quality of the debate. Thus, the administration's plan would not be a dead weight loss on speech; it would have benefits as well as costs. Moreover, the administration could not be blamed for the absence of the line of doctrine we trace back to Sullivan, though it could be held responsible for failure to take the speech-costs of its policies into account.

Despite these possible excuses, it seems likely that the civil libertarian community would give both this expansion of defamation law and the administration that proposed it a very low grade on the bell curve of First Amendment virtue. More interestingly, perhaps, such changes of defamation law, coupled with their particularly intrusive impact on the citizen-publishers of cyberspace, would surely end up forcing the Court to revisit the relationship between defamation and the First Amendment. Thus, in two distinct ways, our fantasy administration would have direct impact on the law of free speech. Its defamation regulations would dramatically burden speech, while the added intrusiveness of those regulations in the context of cyberspace would force the Court to take the conflict between defamation law and the First Amendment seriously.

Fortunately, all of this is no fantasy. Change the "civil lawsuit between private parties" from a defamation case to an intellectual property case and everything I have described is simple reality. The last eight years have seen a striking expansion of intellectual property law, in ways that significantly burden speech, and the Clinton Administration has played a major, and thoroughly discreditable, role in the process. Indeed, if one focuses on all of the Administration's proposals - successful, unsuccessful, and currently pendinga remarkable picture emerges, a picture in which concern for First Amendment values seems entirely over-shadowed by a commitment to intellectual property maximalism. All the defamation law "reforms" I mentioned-liability for online service providers, extension of the scope, reach, and term of rights, increases in criminal penalties and civil damage awards, attempts to prohibit or discourage speech-technologies that could be used to facilitate anonymous defamation, restriction of fair use-have their counterparts in the Clinton Administration's intellectual property proposals.

The Clinton Administration gave an early lead in all matters relating to 
intellectual property to the Commerce Department's Patent and Trademark Office ("PTO"), which proceeded to go on a binge of protectionism. The PTO supported extensions of copyright, patent, and trademark, the creation of entirely new intellectual property rights to cover facts, the criminalization of devices that might be used to threaten copyright protection systems (even if they had other legitimate uses), the use of trade treaties to enforce and extend a maximalist view of intellectual property outside the United States, and the trade sanctions to back up that view. ${ }^{18}$ Some of these measures had fairly obvious implications for speech. For example, one claim of the Clinton Administration White Paper was that Internet Service Providers ("ISPs") were strictly liable for copyright violations committed by their subscribers. ${ }^{19}$ This was a fairly strange account of existing law offline, and stranger still as a prescription for the world of the Internet. After all, in other contexts, First Amendment law has always had a great solicitude for the role of distributors in the political economy of speech. As a result, it has repeatedly rejected the idea of imposing strict liability on them, whether in libel, obscenity, or elsewhere. ${ }^{20}$ Why should we assume that in copyright law strict liability for distributors did not raise exactly the same concerns?

The Clinton Administration also supported a "Database Treaty," which would have introduced into American law a quasi-property right over facts. ${ }^{21}$ In the face of intense resistance, much of it focusing on the devastating effect such a regime could have on research, debate, and public discourse, the treaty proposal was dropped but a domestic bill was immediately introduced in its place. ${ }^{22}$ The examples go on and on, ranging from the PTO's support for far-

18. See Jonathan Band \& Taro Isshiki, The New Anti-Circumvention Provision in the Copyright Act: A Flawed First Step, 3 CYBERSPACE L. 2 (1999); James Boyle, Intellectual Property Policy Online: a Young Person's Guide, 10 HARV. J. L. \& TECH. 47, 58 (1996); Jessica Litman, Symposium, Copyright Owners' Rights and Users' Privileges on the Internet: Reforming Information Law in Copyright's Image, 22 Dayton L. ReV. 587 (1997); Pamela Samuelson, The Copyright Grab, Wired 4.01, Jan. 1996, at 134; James Boyle, Overregulating the Internet, WASH. TIMES, Nov. 14, 1995, at A17; James Boyle, Sold Out, NY TIMES, Mar. 31, 1996, at E15.

19. See Boyle, Intellectual Property Policy, supra note 18, at 58.

20. For example, take the following analysis of the effects of strict liability online, taken from a libel case, which in turn, quoted an analysis from an obscenity case.

The requirement that a distributor must have knowledge of the contents of a publication before liability can be imposed for distributing that publication is deeply rooted in the First Amendment, made applicable to the states through the Fourteenth Amendment. "The constitutional guarantees of the freedom of speech and of the press stand in the way of imposing" strict liability on distributors for the contents of the reading materials they carry.

Cubby, Inc., v. Compuserve, Inc., 776 F. Supp. 135, 139 (1991) (quoting Smith v. California, 361 U.S. $147,152-53(1959))$. Under pressure from ISPs and others, and in the face of clear skepticism from the judiciary and from scholars and activists, the proposal was dropped. See Jennifer E. Markiewicz, Seeking Shelter from the MP3 Storm: How Far Does the Digital Millennium Copyright Act Online Service Provide Liability Reach?, 7. COMM. L. CONSPECTUS 423 (1999).

21. See, e.g., Jerome H. Reichman \& Paul F. Uhlir, Database Protection at the Crossroads: Recent Developments and Their Impact on Science and Technology, 14 BERKELEY TECH. L.J. 793 (1999).

22. For a fine explanation of the problems with the legislation, see William Patry, The Enumerated Powers Doctrine and Intellectual Property: An Imminent Constitutional Collision, 67 GEO. WASH. L. REV. 359, 360-68 (1999). The most recent version is the Collection of Information Anti-Piracy Act, H.R. 354, 106th Cong. (1999). 
reaching, anti-dilution trademark legislation that could reduce parody and criticism of famous companies, to the regulation of domain names on the Internet, to the attack on fair use and first sale in the digital context, or the extension of the copyright term. ${ }^{23}$ All of these proposals have clear First Amendment problems, problems that one would expect officials to agonize over, even if they ultimately found them insufficiently weighty to doom the proposal in question. In fact, however, the PTO's actual comments were dismissive whenever free speech issues were raised. For example, Bruce Lehman, Commissioner of Patents, testified that

[t]he First Amendment has always provided a completely different standard with regard to liability for actions that constitute speech as compared to actions that constitute copyright infringement. They're really just apples and oranges. And I think it would disserve both areas of law-I know there's been some discussion, some people have attempted to link these two areas of law recently, and I think it does a disservice to both areas of law, even though the same technologies may be involved. And I think it really does a disservice both to the law of the First Amendment and the law of copyright to attempt really to try to analogize from one to the other. ${ }^{24}$

Property isn't speech regulation; it's definitional. Of course, Mr. Sullivan said the same thing about libel law.

Admittedly, this account of the Clinton Administration's role is a little oversimplified. Administrations are not monolithic. The Bureau of Standards' National Telecommunication and Information Agency ("NTIA") was initially given a high profile in the Clinton Administration's plans for the information age and, from my conversations with officials in that agency, seemed concerned by the effects of intellectual property maximalism. Unfortunately, the NTIA proved unable to compete with the larger and better connected bureaucratic players. Soon, rather like Al Gore, but with less credibility, it was reduced to stressing its own importance to the Internet. ${ }^{25}$

The FTC and the Justice Department's Antitrust Division proved rather more skeptical about the unvarying menu of intellectual property expansion. Both political appointees and civil servants outside the PTO saw the danger of anti-competitive effects, costs to consumers and market concentration, particularly in the context of computer networks, where concern about "lockin" effects and path dependency were being popularized by the Microsoft case. To some extent, these countervailing forces prevented the Administration's

23. See, e.g., Sonny Bono Copyright Term Extension Act of 1998, Pub. L. No. 105-298, 112 Stat. 2627; Keith Aoki, How the World Dreams Itself to be American: Reflections on the Relationship between the Expanding Scope of Trademark Protection and Free Speech Norms, 17 LOYOLA L.A. ENT. L.J. 523, 528-31 (1997); Diane K. Wong, Avery Dennison Corp. v. Sumpton, 15 BERKELEY TECH. L.J. 245 (2000); Eldred v. Reno (last updated Aug. 24, 2000) <http://cyber.law.harvard.edu/cc/opinion.html>.

24. NII Copyright Protection Act of 1995: Joint Hearing on H.R. 2441 and S. 1284 Before the Subcomm. on Courts and Intellectual Property of the House Judiciary Comm. and the Senate Judiciary Comm., 104th Cong., 1st Sess. (1995) (testimony of Bruce Lehman, Commissioner of Patents), quoted in Jessica Litman, Reforming Information Law in Copyright's Image, 22 DAYTON L. REV. 587, 588 (1997).

25. I am at a loss to know how to provide footnote support for this shameless reliance on anecdote, gossip, and personal experience. Presumably, I should write a newspaper article asserting it, which I could then cite as textual evidence. 
Internet strategy from being completely dominated by an agenda of intellectual property maximalism. Nevertheless, it is worth noting two things. First, these countervailing forces were largely concentrated around the potential negative economic effects of intellectual property expansion rather than their effects upon speech tout seul, though the two aspects are linked, of course. Second, even within the economic realm, the links between antitrust policy and intellectual property were imperfectly understood. ${ }^{26}$

During 1999, for example, we were treated to the sight of the Clinton Administration simultaneously trumpeting the importance-given network effects-of devoting significant government resources to prosecuting Microsoft for violating the antitrust laws, and championing intellectual property expansions that would make it much easier for the next generation of Microsofts to maintain just such a dominant position in the future. Thus, even in the economic realm, the potential dangers that expansive intellectual property rights present were only inconsistently recognized, and the potential effects upon speech were not recognized at all.

There are exceptions to this statement. When the United States proposed a new treaty covering intellectual property rights in databases at the World Intellectual Property Organization, senior Administration science officials seem to have played an important role in explaining the depth of opposition to the proposal among researchers and civil liberties groups. ${ }^{27}$ When a domestic counterpart to this proposal was introduced, the Office of Legal Counsel ("OLC") issued a particularly fine memorandum to Congress questioning its constitutionality on a number of grounds. ${ }^{28}$ Slowly, things may be getting even better. But the overall record is clear and, in speech terms at least, remains a pretty dismal one.

At some point, if this pattern continues to hold, the second part of my prediction may come to pass: The Supreme Court will be forced to confront the tensions between intellectual property law and the First Amendment. Already, the extremism of the Administration's proposals and the severity of their impact on promising new speech technologies has prompted new attention to constitutional issues in the intellectual property area. In addition to the OLC memo, there was a court challenge to copyright term extension, which raises public trust, copyright clause, and First Amendment issues. ${ }^{29}$ In fact, the next ten years is likely to present a flowering of constitutional litigation of intellectual property questions, addressing exactly the imbalance described

26. See James Boyle, Missing the Point on Microsoft, SALON (Apr. 7, 2000) $<$ http://www.salon.com/tech/feature/2000/04/07/greenspan/index.html>.

27. See Louis Jacobson, Dueling Over Data, 30 NAT'L L.J. 64, No. 2, (1998); Robert M. White, Taking on the Database Challenge—and Winning, 100 TECH. REV. 65 (1997).

28. See Memorandum from William Michael Treanor, Deputy Assistant Attorney General, Office of Legal Counsel, U.S. Department of Justice, to William P. Marshall, Associate White House Counsel 23 (July 28, 1998) [hereinafter OLC Memo].

29. See <http://cyber.law.harvard.edu/eldredvreno/legaldocs.html> (last updated Aug. 24, 2000). 
above in the analogy to New York Times $v$. Sullivan. ${ }^{30}$ This litigation will be driven, above all, by a particularly toxic combination: the lack of balance in the maximalist intellectual property policies of recent years, the degree to which those policies, when applied online, will actually burden the quotidian speech and research of ordinary citizens, and the geometric increase in economic importance of intellectual property rights in a networked information society. ${ }^{31}$ In other words, we have had an increase in the level of intellectual property rights, a technologically-driven increase in the burden each of those rights imposes on an average citizen, and a raising of the economic stakes involved. The main barrier to the challenges that will inevitably arise is the constitutional exceptionalism around intellectual property. Why is the treatment of intellectual property so anomalous?

III

\section{THE FIRST AMENDMENT AND INTELLECTUAL PROPERTY}

There is no case-no single pronouncement-that speaks to the First Amendment constraints on intellectual property law with the simple authority of New York Times v. Sullivan. There are certainly nods and becks in the right direction: Feist Publications, Inc. v. Rural Telephone Service Co. ${ }^{32}$ Campbell v. Acuff-Rose Music, Inc., ${ }^{33}$ and a few other cases have provocative snippets that suggest, for example, that it would not be constitutional for Congress to eliminate the fair use privilege in copyright law. At moments it also seems as though the Court is saying that the distinction between idea (noncommodifiable) and expression (commodifiable) has constitutional as well as statutory authority behind it, but these cases are the exception rather than the norm in the Court's intellectual property jurisprudence.

Thus, for example, Congress conveyed the exclusive right to promotional uses of the word "Olympic" to the United States Olympic Committee ("USOC"), which then used that right to prevent a non-profit corporation, San Francisco Arts \& Athletics, Inc. ("SFAA"), from organizing a "Gay Olympic Games." " The Court concluded that the First Amendment was not implicated, either by the original grant or by its subsequent use. ${ }^{35}$ Applying a relaxed, not to say supine, standard of review to the initial legislation, the Court analyzed the issue as one of property rights, not free speech. In words that are strikingly different from those of Sullivan, the Court dismissed any associated collateral damage to free expression:

30. See supra text accompanying notes 14-17.

31. See James Boyle, Shamans, Software and Spleens; LaW And the Construction of THE INFORMATION SOCIETY ix-16 (1996).

32. 499 U.S. 340 (1991).

33. 510 U.S. 569 (1994).

34. 36 U.S.C. $\S 380$ (1978).

35. See San Francisco Arts \& Athletics, Inc. v. United States Olympic Committee, 483 U.S. 522, 538-42 (1987). 
The mere fact that the SFAA claims an expressive, as opposed to a purely commercial, purpose does not give it a First Amendment right to "appropriat[e] to itself the harvest of those who have sown." The USOC's right to prohibit use of the word "Olympic" in the promotion of athletic events is at the core of its legitimate property right. ${ }^{36}$

A similar argument, of course, would tell us that

the mere fact that the signatories of the offending advertisement in Sullivan claimed they were criticising a government official rather than maliciously bad-mouthing a neighbour does not give them the First Amendment right to utter falsehoods that destroy a man's reputation, his dearest jewel. Mr. Sullivan's right to prevent the spread of injurious falsehood about him lies at the very core of his legitimate reputational right. ${ }^{37}$

And yet that is exactly the argument the Court in Sullivan rejected.

In fact, of course, the two cases are different; the state libel law in Sullivan was facially neutral, while Congress created through special legislation a unique property right over the word "Olympic," a right held only by the USOC and not subject to the normal defenses in a trademark case. But these differences hardly shore up the court's reasoning in the Gay Olympics case, quite the reverse.

Having divided the case into two parts-(1) a review of a facially neutral law conveying a property right, and (2) a private action seeking enforcement of that property right through the courts - the Supreme Court could then declare that there was no state action involved in enforcing the USOC's property right against the SFAA:

Most fundamentally, this Court has held that a government "normally can be held responsible for a private decision only when it has exercised coercive power or has provided such significant encouragement, either overt or covert, that the choice must in law be deemed to be that of the [government]."... The USOC's choice of how to enforce its exclusive right to use the word "Olympic" simply is not a governmental decision. There is no evidence that the Federal Government coerced or encouraged the USOC in the exercise of its right. At most, the Federal Government, by failing to supervise the USOC's use of its rights, can be said to exercise "[m]ere approval of or acquiescence in the initiatives" of the USOC. This is not enough to make the USOC's actions those of the Government. ${ }^{38}$

It is striking to compare these words with the equivalent passage from Sullivan:

Although this is a civil lawsuit between private parties, the Alabama courts have applied a state rule of law which petitioners claim to impose invalid restrictions on their constitutional freedoms of speech and press. It matters not that that law been applied in a civil action and that it is common law only, though supplemented by state statute... The test is not the form in which state power has been applied but, whatever the form, whether such power has in fact been exercised. ${ }^{39}$

36. United States Olympic Committee, 483 U.S. at 541 (citing International News Service v. Associated Press, 248 U.S. 215, 239-40 (1918)).

37. I am told that I should insert a footnote here to point out that this is not a real quotation, merely a hypothetical transposition of the Court's argument in SFAA to the facts of Sullivan.

38. United States Olympic Committee, 483 U.S. at. 546-47 (citing Blum v. Yaretsky, 457 U.S. 991, 1004-05 (1982)).

39. Sullivan, 376 U.S. at 265. 
This must surely lead one to ask whether courts applying intellectual property rules will be applying "rule[s] of law which ... impose invalid restrictions on ... constitutional freedoms of speech and press." Many courts have treated this question as a simple one, but it is hardly that. ${ }^{40}$

The laws of intellectual property affect freedom of speech in a number of distinct ways. First, and most importantly, intellectual property laws may promote speech. By adding "the fuel of interest to the fire of genius," ${ }^{41}$ these laws may encourage the production of literary, artistic, scientific, political, and other works, enrich public debate, and allow the iconoclast and the dissenter to dream of supporting themselves by creating works and then selling them in the marketplace. "[T] he Framers intended copyright itself to be an engine of free expression. By establishing a marketable right to use one's expression, copyright supplies the economic incentive to create and disseminate ideas." Of course, there are other incentive systems for the production of such works, ranging from altruism and the love of sharing one's work to the search for reputation and to other indirect market benefits. The importance of intellectual property here is in promoting the work that is at the margin, the work that would not be created but for the market leverage conferred on the creator by the bundle of intellectual property rights. Intellectual property also encourages speech in another way: $:^{43}$ It offers rights-owners some degree of continuing control over their works, a guarantee of semiotic stability, which might lead a speaker or thinker or artist to make a precious work public, secure in the knowledge that he may call on the state to forbid others from transforming its meaning in certain ways. Of course, as Rebecca Tushnet points out in a fine recent paper, the fact that intellectual property may encourage some speech does not end the question of the constitutionality of a particular intellectual property rule. Hate speech regulation may encourage the speech of some as it regulates the speech of others. That is hardly thought to settle the question of its constitutionality. ${ }^{44}$ Incentive effects are not the end of the story; intellectual property also restrains speech.

40. For example, one still hears the argument that, because the Constitution grants power to Congress to create a copyright system, any particular copyright law cannot be inconsistent with the First Amendment. By this logic, since the Constitution gives Congress the power to levy taxes, any tax-including one aimed solely at African-Americans-would be immune from scrutiny under the Equal Protection Clause. Some copyright regimes may be constitutional; that does not mean that all copyright regimes must be.

41. The words were actually used by Lincoln to describe the operation of the patent rather than the copyright system. Speech by Abraham Lincoln to the Springfield, Ill., Library Ass'n (Feb. 2, 1860), in COMPLETE WORKS OF ABRAHAM LINCOLN 113 (John G. Nicolay \& John Hays eds., 1905).

42. Harper \& Row, Publishers, Inc. v. Nation Enterprises, 471 U.S. 539, 558 (1985). But see Stephen Fraser, The Conflict Between the First Amendment and Copyright Law and Its Impact on the Internet, 16 CARDOZO ARTS \& ENT. L.J. 1, 19-20 (1998) (arguing that this is probably an inaccurate account of the original understanding of copyright).

43. Neil Netanel would add to this list the beneficial speech-effects of copyright: its function in supporting "a sector of creative and communicative activity that is relatively free of state subsidy, elite patronage, and cultural hierarchy." Neil Weinstock Netanel, Copyright and a Democratic Civil Society, 106 YALE L.J. 283, 288 (1996).

44. See Rebecca Tushnet, The Engine of Free Expression (forthcoming article). 
First, in the simplest sense, intellectual property rights allow individuals to call upon the state to prevent someone from speaking or expressing themselves in a particular way. This may involve a simple refusal to let the speaker use some sign, signifier or text in their message, or it may involve a refusal to let them transform it in some way, whether contextually or otherwise. ${ }^{45}$ In either case, this type of effect strikes most directly at the person who cannot paraphrase around the restraints posed by intellectual property, who needs to use the particular text or sign in question to convey her message. For example, the San Francisco Arts and Athletics Association wants to assert its right to link its community with the noble ideals and images of the Olympic games. Running a "Gay Faux-Greek Athletic Thingamajig" just isn't the same. The Nation magazine wishes to use President Ford's own words from his autobiography in describing his decision to pardon President Nixon. ${ }^{46}$ In each of these cases, it is precisely the authenticity of the sign or the words that the speaker feels is crucial to his speech.

Like most legal regimes, intellectual property's restraints may run beyond the actual limits of the legal rights themselves, particularly where the threat of suit is used by powerful individuals and organizations against those without access to lawyers or the money to command their talents. A judge in one of the Church of Scientology's many intellectual property cases observed that "[a]lthough the [Religious Technology Center] brought the complaint under traditional secular concepts of copyright and trade secret law, it has become clear that a much broader motivation prevailed - the stifling of criticism and dissent of the religious practices of Scientology and the destruction of its opponents." ${ }^{47}$ The effects of chill may be particularly important to free speech doctrine on the Internet. There, the well-funded media plaintiffs who have played such a role in establishing free speech law give way to the "citizenpublishers" of cyberspace who have no such resources. ${ }^{48}$

Beyond this familiar chilling effect lies the possibility of using intellectual property as an indirect restraint on speech, to deny the speaker access to his or her chosen channel of communication. Copyright infringement, in particular, is often declared to be a strict liability tort. If one cannot use the threat of litigation to discourage the speaker, it may be possible to threaten the speaker's internet service provider with contributory infringement, ${ }^{49}$ or to sue Network

45. For good examples of both tendencies in the Scientology cases, see Church of Scientology Int'l v. Fishman, 35 F.3d 570 (9th Cir. 1994); New Era Publishers, Int'l v. Henry Holt \& Co., 873 F.2d 576 (2d Cir. 1989); Religious Tech. Ctr. v. Lerma, 908 F. Supp. 1362 (E.D. Va. 1995); Religious Tech. Ctr. v. F.A.C.T. NET, Inc., 907 F. Supp. 1468 (D. Colo. 1995); Religious Tech. Center v. Netcom On-Line Communic. Servs., 907 F. Supp. 1361 (N.D. Cal. 1995).

46. See Harper \& Row, 471 U.S. at 539.

47. Lerma, 908 F. Supp. at 1377-78.

48. The Supreme Court has indicated that the financial and practical burden of complying with particular legal rules are an important First Amendment consideration. See, e.g., Freedman v. Maryland, 380 U.S. 51 (1965) (noting the effect of lengthy litigation processes on a film censored because it was not properly submitted to the State Board of Censors).

49. Though the Digital Millennium Copyright Act gives a qualified immunity to ISPs, it conditions 
Solutions for failing to change a domain name that allegedly infringes a trademark.

Intellectual property regimes, particularly online, may have more subtle effects in shaping the architecture, political economy, and structure of preferences in our speech universe. Some intellectual property thinkers, including a number in government employ, would like to see intellectual property protections explicitly redefined by, for example, commodifying facts, restricting fair use, and abolishing first sale. Their goal is to move toward a payonly-per-view universe, in which the Internet's efficiencies are used to allow for the levying of microcharges on every use of information, rather than the cruder, but also looser system we have now, with its broad range of free, subsidized, borrowed, and second-hand sources. Of course, pay-per-view, or per screen, would indeed allow for sophisticated price discrimination by content providers, perhaps providing high-quality access to the wealthy. ${ }^{50}$ One wonders though, what the price to the universe of speech would be. After all, information is hard to value before one has it, particularly when one's resources are limited and one's ability to experiment thereby constrained. Much of learning is serendipitous and unplanned, and the pursuit of apparently non-productive knowledge is both inherently pleasurable and practically useful. One's current preferences are formed by one's past experiences and those, in turn, are shaped by the costs of experimentation, on which legal rules may have a considerable influence. ${ }^{51}$ Does one really want to make it harder (and more expensive) for the poor child to learn that "aimless browsing" may be a very smart move indeed, or for the next auto-didact to pursue the meandering course of intellectual development that produces a new synthesis or a striking point of view?

Moreover, if one wants to move to a world in which reading someone else's e-books may be a contract violation, and possibly a crime, the anonymous, decentralized, and protean architecture of the Internet itself starts to seem like a bug rather than a feature. Architectures, whether real or virtual, are powerfully influenced by the underlying structure of rights and markets, as well as by technological feasibility. The suburb, the mall, and the tenement are all based in part around the social organization of work, life, and market, an organization in which property regimes have an important role. It would be ironic indeed if the openness and resistance to centralized public or private control that makes the Internet so attractive as a medium for the distribution of

that immunity on a set of complaint and removal procedures that are hardly designed to encourage speech. See Digital Millenium Copyright Act of 1998, Pub. L. No. 105-304, 112 Stat. 2860.

50. For an argument that the government could condition an increased (and socially beneficial) ability to price discriminate on the acceptance by rightsholders of a variety of limitations of intellectual property rights in the public interest, see William W. Fisher III, Symposium on the Internet and Legal Theory: Property and Contract on the Internet, 73 CHI.-KENT L. REV. 1203 (1998). For an argument that intellectual property law itself already operates to facilitate certain broad classes of price discrimination, see Wendy J. Gordon, Symposium on the Internet and Legal Theory: Intellectual Property as Price Discrimination: Implications for Contract, 73 CHI.-KENT L. REV. 1367 (1998).

51. The assumption of exogenous preferences notwithstanding. 
speech, ${ }^{52}$ or as a persistent social space, were to be whittled away in the name of facilitating a particular business plan for making money off content, and the expansionist intellectual property rights on which that plan depends. Rather than being the engine of free expression, copyright would be the nemesis of the structures that permit such expression.

\section{CONCLUSION}

My argument here has had a double goal. On the one hand, using the analogy of New York Times $v$. Sullivan, I have argued that courts and scholars should look more critically at the consistency of particular intellectual property rules with the First Amendment. With or without the Clinton Administration, inside or outside of cyberspace, this reexamination is a necessary one. We need a Sullivan for intellectual property. On the other hand, I want to stress the particular role that both the Clinton Administration and cyberspace have to play in this story. Because the executive branch has a strong impact on intellectual property policy, both domestically and internationally, one must amend Professor Volokh's conclusion that particular administrations do not have much of a role in speech regulation. The Clinton Administration really

52. A critic might say at this point, "This sounds like a definitionalist First Amendment absolutism, in which 'regulation' of speech is always bad and all the interesting questions about speech are either ignored, assumed, or explained away." That is not my position ( I hope), but like a number of scholars who are sometimes critical of conventional First Amendment analysis, I find that, in the online world, the ACLU and I are much more likely to agree. Why? The question is a good one, and deserves a better answer than I give here. Broadly speaking, my answer is that the Internet is different in important respects from other communications media. First, as a communications medium, it is more resistant (though certainly not immune) to both private and public power than is broadcasting or the daily newspaper. Thus, the cure of "more speech" is not as hollow as it might be in a world where ordinary citizens cannot hope to publish their opinions. I don't want to make too much of this difference-Disney can still drown out http://www.rtmark.com-but there is a difference. Second, unlike other media, effective regulation of the Internet almost has to be technological in nature and global in scope. Thus, the architecture you put in place to ensure that teens in Schenectady cannot see indecent images will be available to stop activists in Senegal and Singapore from getting access to information on birth control, or government corruption, or the comparative infant mortality rates of boys and girls. Whatever one's views on speech, this point matters. If, by proposing a municipal ordinance in the Midwest on images degrading to women, a feminist activist automatically granted an additional level of coercive power over Afghan women's dress and education to the Taliban, she might well think twice before proceeding. This kind of unintended technical generalization over the globe is not the same as the normative universalization that Kantian morals prescribe, or the hypothetical generalization over different viewpoints or types of speech that First Amendment scholars have always used to restrain those eager to regulate speech ("Would you support such a rule if it could be used against pro-choice marchers?"). Yet, it does have a similar chastening effect on moral positions; it argues powerfully for care and scrutiny when Internet regulation is proposed. The claim is not that regulating the Nazis marching through Skokie will cross a conceptual barrier and thus set us on a slippery slope to book burning, but rather that the technological standards proposed to implement individual regulatory initiatives will have unintended global consequences. The universalizing move comes from technology, not deontology: network effects, not Kantian hypotheticals. This is an important point in its own right. It also suggests that the divisions between First Amendment scholars may be transformed online. Surprisingly, though, it has received practically no attention. The work of Larry Lessig is a signal exception. See generally LAWRENCE LESSIG, CODE AND OTHER LAws OF CYBERSPACE (1999). I hope to develop this idea in a later work; for the moment, these asides will have to take the place of developed argument. 
has leant its support to a continuing program of intellectual property expansion in ways that seem both unwise and unconstitutional.

But why look at cyberspace in particular? A myopic focus on a particular medium is always suspect, and rightly so. In particular, why argue that online intellectual property disputes will force courts to confront the unresolved tensions between their intellectual property analyses and their First Amendment analyses? There are three main reasons. First, in cyberspace, intellectual property will be closer to the reader, the user, and the citizen than it has ever been before..$^{53}$ The acts that trigger intellectual property scrutiny, and copying in particular, are the very heart of the networked environment. They have gone from being acts that an individual user has to work quite hard to accomplish (setting type to reprint a book) to being acts that were within reach (photocopying, taping) to being acts that it is almost impossible to avoid, at least if one is to believe the Clinton Administration that even storing a document in RAM or disk cache amounts to copying. Intellectual property is on the desktop, both literally and figuratively.

Second, the legal category of intellectual property will increasingly include both familiar property rights and less familiar state-backed technologies of control and surveillance, digital fences, universal ID's, and so on. This in turn will heighten the tensions between intellectual property, privacy, and speech. The Digital Millennium Copyright Act is a fine example of the new genre.

Finally, the larger the network, the higher the stakes. Paradoxically, the very network effects that make alternative ways of supporting innovation feasible have been seen by the Clinton Administration and by many of the dominant content providers as a reason to extend their rights even further. If this process continues, the relationship-both positive and negative-between intellectual property and speech will become clearer and clearer. In this case, political economy actually will make ideological contradiction manifest to the meanest understanding.

The Clinton Administration's intellectual property policies have been astoundingly one-sided and poorly thought out. Though the Administration presents itself as cyber-savvy, these policies represent the absolute antithesis of everything one should revere about the Internet, and indeed threaten to make the Internet's decentralized anonymous architecture seem like a bug rather than a feature. But I have to concede one point. When it comes to exposing the tensions between intellectual property and speech, the Clinton Administration's role may well prove to be pivotal—if entirely unintended.

53. See BOYLE, supra note 31, at 135-39; Litman, supra note 18, at 610-12. 